\title{
EXPERIENCES AND SUPPORT NEEDS OF CHILDREN WITH BROTHER OR SISTER WITH DISABILITY
}

\section{Authors:}

Tiiu Tammemäe (Ph.D.)

Tallinn University (Estonia)

Lii Lilleoja

Tallinn University (Estonia)

Mari-Liis Valma

(Estonia)
Lectors:

\author{
Magdolna Nemes (Ph.D.) \\ University of Debrecen (Hungary) \\ Katalin Mező (Ph.D.) \\ University of Debrecen (Hungary)
}

E-mail address of the first author: tiiu.tammemae@,tlu.ee

Tammemäe, Tiiu; Lilleoja, Lii \& Valma, Mari-Liis (2021). Experiences and Support Needs of Children with Brother or Sister with Disability. Különleges Bánásmód, 7. (1). 69-81. DOI 10.18458/KB.2021.1.69

\begin{abstract}
Abstrakt
There are many children with special needs whose siblings play an important role in their lives for a longer time than other family members. Longer life expectancy and the deepening of disabilities bring along a higher need of being taken care of. When the parents grow older it is often the siblings who become the caretakers. Meyer \& Vadasy (2007) found that if siblings of children with SEN get proper support and information while growing up, the well-being of sibling with special needs also increases. Relationship with sibling with special needs influences development of adaptability and self-esteem, this influence can be positive or negative (Burke, 2008). The parents of the children with SEN have many ways to receive information or help for the family - doctors, therapists, consultants, teachers, books etc. The siblings in their turn usually get their information from the parents. (Conway \& Meyer, 2008) Family members in different ages need different information. Therefore, there should be a research on what kind of experiences do the siblings of the disabled child need, how their needs and well-being is guaranteed and what kind of support they need. The aim of this study is to describe the experiences of brothers and sisters with sibling with special needs, try to understand their need for support and find out the need for support groups and camps.
\end{abstract}

Keywords: siblings, special need, family, supporting, experiences

Discipline: pedagogy 


\begin{abstract}
Absztrakt
FOGYATÉKOS GYEREKEK TESTVÉREINEK TAPASZTALATAI ÉS TÁMOGATÁSI SZÜKSÉGLETEI

Nagyon sok olyan különleges bánásmódot igénylő gyermek van, akinek a testvérei hosszabb ideig játszanak fontos szerepet az életükben, mint más családtagok. A meghosszabbodó születéskor várható élettartam és a mélyülő fogyatékosság magával hozza a magasabb gondozási igényt. Amikor a szülők megöregszenek, gyakran a testvérek lesznek a gondviselők. Meyer és Vadasy (2007) úgy találta, hogy ha a sajátos nevelési igényű gyermekek testvérei megfelelő támogatást és tájékoztatást kapnak felnevelésük/felnövekedésük során, akkor a sajátos nevelési igényú testvér jól-léte is növekedést mutat. A sajátos nevelési igényű gyermekkel való kapcsolat növeli az önbecsülést és az alkalmazkodóképességet; a befolyás lehet pozitív és negatív is (Burke, 2008). A sajátos nevelési igényú gyermek szüleinek számos lehetőségük van, hogy tájékoztatást vagy segítséget kapjanak a család számára pl. orvosok, terapeuták, szakértők, tanárok, könyvek stb. A testvérek az információkat többnyire a szüleiktől kapják. Szükség van olyan kutatásokra, melyek feltárják, milyen élményekre van szükségegük a fogyatékkal élő gyerekek testvéreinek, hogyan lehet a szükségleteiket és a jól-létüket biztosítani és milyen támogatást igényelnek. Jelen tanulmány célja, hogy bemutassa a sajátos nevelési igényủ gyerekek testvéreinek élményeit, megpróbálja értelmezni, hogy milyen támogatásra van szükségek, valamint a támogató csoportokra és táborokra való igényüket.
\end{abstract}

Kulcsszavak: testvérek, speciális szükséglet, család, támogatás, élmények

Diszciplína: pedagógia

\section{Family}

\section{as the Child's Environment of Growth}

In the early process of socializing it is the family that shapes and guides the behavior and identity of the child. Networks of families are essential in protecting and looking after the future generations (Underdown, 2006). Barker \& Chang (2013) brought out the different functions of a family: satisfying the basic needs of its members, nurturing the children and socialising them, ensuring the wellbeing and support. What is important is how the material and emotional needs of the members of a family are granted.

The ecological environment can be described as a whole made of structures within each other. The internal part of the model is a diaad - a dual relationship. If one member of the diaad develops then so does the other. Therefore, it can be concluded that the developmental changes of a child also affect its caretakers - parents, grandparents, teachers. The mutual interaction also takes place in the diaad with the siblings. (Bronfenbrenner, 2009) If a person is not capable of regulating one's behavior and development (like children and people with special needs) then their behavior and decisions are guided by their parents or the specialists working with them (Heckhausen, 2008)

A social system is a whole that works due to the mutual dependability of its different parts. An individual is analyzed by being observed in an environment - the social network he belongs to. 
The base of an analysis that takes into consideration all the steps from micro to macro level is the learning of children and youngsters and their development in accordance with the environment (Klefbeck \& Ogden, 2001). The development goes both ways which means that the children influence their parents the exact way as the opposite. This supports the theory that all development is influenced by the environment where it occurs (Wodarski \& Dziegielewski, 2002, 85).

Minuchin (1974) claims that a family has 2 kinds of functions. The internal - psychosocial protection of the members, and external - adaptation and transmission of the culture. Culture is a part of the macro system that is related to the overall coping of a family. In a family with a child with special needs culture can influence the way they seek for assistance, the attitude towards professional help and intervention as well as the coping strategies that are accepted.

The coping of children on micro and macro level depends on the mental health of the parents, the quality of their relationship and the relationship between siblings and the style of upbringing. (Kovshoff, Cebula, Tsai \& Hastings, 2017). Siblings have a specific socialising influence on each other's behavior. Age difference between the siblings allows the family to use modelled learning - social skills are acquired faster, younger children learn from the older ones and the overall coping within the age group improves. (KeltikandasJärvinen, 2013; Mangs \& Martell, 2000).

The Diagram of Relationships Between Siblings

Kovshoff, Cebula, Tsai and Hastings (2017) have created a diagram (Fig 1) that helps to understand the relationships between the child with special needs and the siblings. The diagram is based on the elements of family system theory, the model of stress (Double ABCX), the model of stress and predisposition to disease and the ecological system theory. The micro system is directly related to the experiences of the siblings of the child with SEN, the meso and micro system affect each other mutually, the exo system affects the siblings indirectly and the macro system includes wider social and cultural factors.

The child in the diagram is described as an active practitioner who shapes his environment. One of the key factors on micro and macro level is ,an event" that could mark a sibling with special needs, behavioral issue or communication skills of the child with SEN, a sibling with age-appropriate development etc.

The impact depends on demographic variables (the sex and age of the children), internal challenges of the child and coping mechanisms (preventive coping strategies, positive self-esteem, endurance) as well as how the child himself interprets the event.

The siblings 'coping on micro and macro level is affected in addition to ,the event" by variables connected to the family, such as the mental health of the parents, the quality of their relationship, the support from the grandparents, friends, school or workplace and support mechanisms. The exo and macro system involves factors like local political structures, media, religion and legislation. An important element is coping that might be psychosocial adaptation, the quality of relationship between siblings, academic accomplishments or overall satisfaction with life.

There is a hypothesis that the coping of the siblings of a child with SEN in its turn shapes the micro and meso systems. Time is an important factor because some of the factors in the diagram are constant throughout the life while earlier experiences shape the later coping. 
Figure1. Sibling Embedded Systems Framework. (Source: Kovshoff, Cebula, Tsai \& Hastings, 2017)

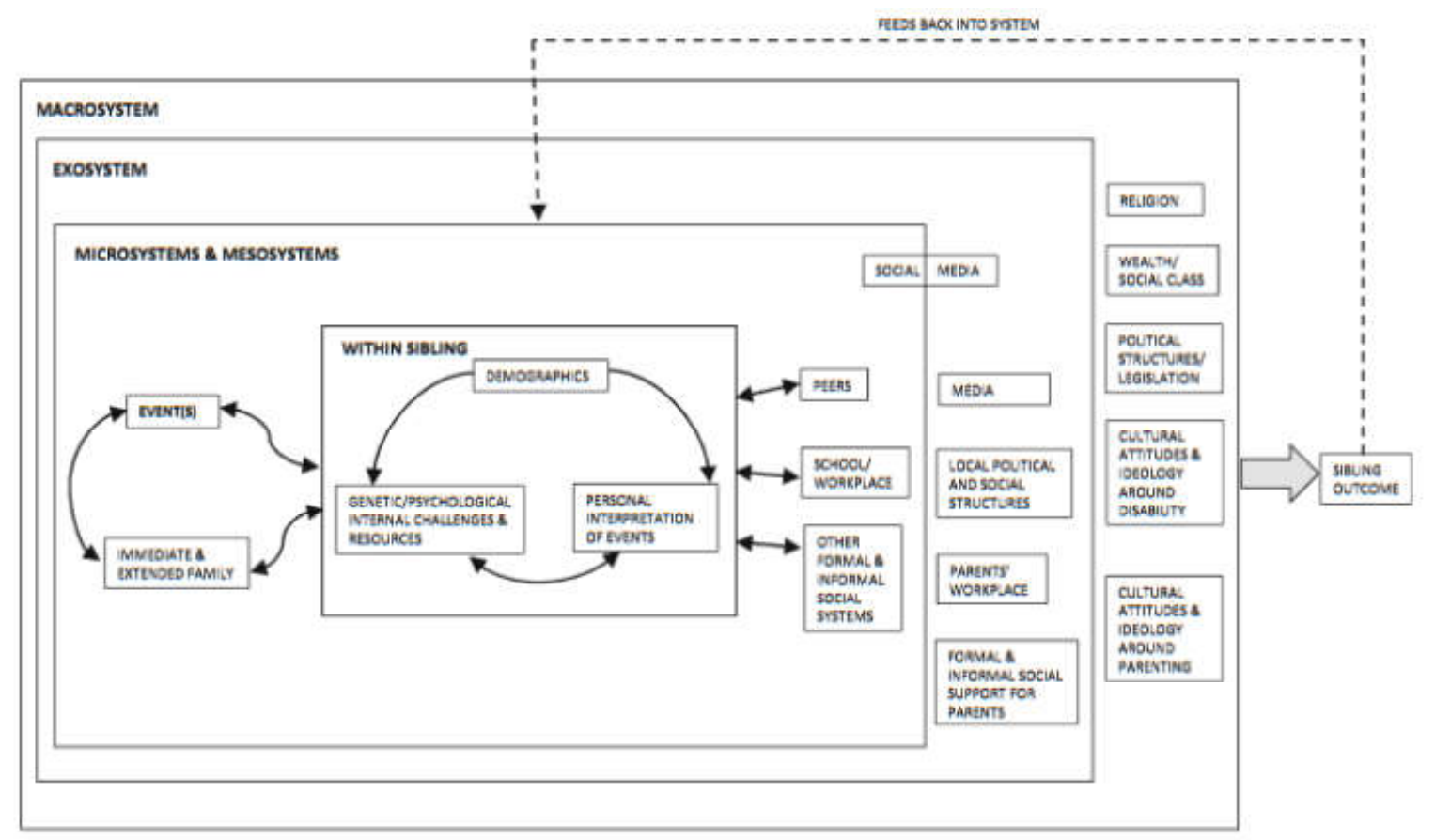

The Influence of Children with Sen to the Development of their Siblings

Children with SEN are often characterized as ignorant to behavioral norms and lacking socialemotional skills. The siblings in their turn are affected by these behavior patterns and react to them. The child with SEN and the siblings affects mutually each other's social-emotional competence which creates a relationship that might maintain or undermine the achieved competencies. Not only they affect each other as a person through mutual communication but the communication creates a certain dynamic in the relationship that also affects future interaction (Bedford \& Volling, 2013)

Hogan (2012) claims that when growing up in a family with a child with SEN the siblings while growing up have a chance to understand the challenges that people with special needs need to cope with. Also, they are most likely more helpful towards others. At the same time the siblings have a higher risk to become miserable, feel sad and even experience depression compared to the children who do not have a sibling with SEN. Older siblings often help the siblings with SEN more. They develop certain skills for taking care of someone and these skills will be beneficial in the future when it comes to their children or their elderly parents. They adapt better, are more understanding and helpful compared to the ones who do not have that kind of experiences when growing up.

Therefore, a family has a very important role in shaping the child to become a coping individual and a family can be considered a whole social 
system that works by mutual dependence. This means that the parents, the child and a parent as well as the siblings are depending on each other and also affecting one another. The exact effect that a sibling with SEN creates depends on multiple aspects like the individual factors, growing environment and culture. The effect can be both positive and negative.

\section{Family Dynamics in a Family where one Child has SEN}

Often the family dynamics are different in families where a child with SEN is growing up compared to other families. The siblings of the child with SEN also often have different goals and behaviorur patterns compared to other children and youngsters who do not have a sibling with SEN (Hogan, 2012)

Considering a family as a micro system and the diaads within, Mitchell (1983, reference by Veisson, $2000,7)$ brings out problematic areas that affect families where a child with SEN is growing up:

- Parents 'coping individually and as a couple, acceptance of the child with SEN

- Mother's depression, guilt and occupation with special needs

- The amount of attention that the mother shares to the siblings; the excessive exploitation of siblings by the mother to take care of the child with SEN.

- The amount of attention that the father shares to other siblings; the excessive exploitation of siblings by the father to take or of the child with SEN.

- The withdrawal of the father when it comes to looking after the child with SEN, the psychological and physical presence

- The attitude of other children in the family towards the one with SEN: guilt, shame, fears, adversative feelings.
The family relationship has a significant impact to a child's coping. The unfavourable changes come with decrease of mood and anxiety. Therefore, it is of extreme importance to share any information with the child when it comes to changes in the family's life. The parents have various feelings when they find out about the SEN of their child. The information that is shared with other siblings and the way it is shared might affect the way the whole family functions.

Occasionally the siblings of the child with SEN have tasks that normally should be covered by grownups. Aldridge and Becker (1993, reference by Underdown, 2006) have reffed to such siblings as „young caretakers" and brought out that their life is limited due to them taking care of their family member. Such responsibility in a young age to take care of someone might damage the child's mental and physical health. The youngsters themselves have described how such way of life affects them and what they feel

- The feeling of being different, detached from companions; relationship problems

- Lack of time for homework, play and leisure time

- Conflict between the needs of oneself and the one being taken care of that might lead to anger and feeling of guilt

- Too few accomplishments in school that will lead to difficulties in the older age

Ronald Wiman (1990; Reference by Kiis, 1999) brings out the preconditions of social coping:

- abilities - the necessary physical and mental resources;

- motivation - the person's own wish to cope in a certain situation;

- knowledge - information and knowledge that help to cope in a certain situation;

- skills - the skills to act according to the situation; 
- opportunities - suitable environmental conditions that make it possible to cope.

The first 4 resources form the overall actual competency for coping and the fifth one covers the environmental factors. If a person cannot cope socially the coping problem might be due to one or more coping conditions are not met at all or met partially. The ones who have the option to receive mental social support cope better with stress and traumatic situations. Social support can be practical, material or emotional (Baumeister, Faber \& Wallace, 1999). By researching the everyday coping of the siblings of the child with SEN the methods can be divided into 4 categories: aimed at solving the problem or acting on it, aimed at emotions or thinking, aimed at the support from a third party or denial and ignoring.

It can be said that the needs of the family members in a family with a child with SEN (parents, siblings) can be often different from other families. Both the parents and other children of the family face various problems and need to manage difficult emotions and situations. The birth of a child with SEN could change a couple's relationship, the ability of the parents to divide the attention between the children, create adversative feelings for the siblings and cause a lot more duties for them.

\section{Empirical Research of the Experiences of the Siblings of the Child with SEN}

\section{Metodology of Research}

The aim of an empirical research is to describe the experiences of the siblings of a child with SEN, try to understand their support needs and find out about the need for support groups and camps.

Due to the purpose of the thesis the following research questions have been raised:
- What kind of experiences do the other children of the family have in connection with the child with SEN?

- What kind of support do the siblings of the child with SEN need?

- Is there a need for camps and support groups for the siblings of the child with SEN?

A qualitative research method is used in the research that values the importance of opinion and the detailed approach even with only few participants. A half-structured interview is used for data collection. Different sources show that an interview can be considered an effective way to collect data as it allows in addition to factual knowledge to get familiar with the person's perspective, opinions, feelings and experiences while maintaining the specificity of one's linguistic performance and giving a detailed overview (Saldana, 2011; Laherand, 2008). Open-ended questions help the interviewee to better explain their points of view and feelings. An oral interview is also suitable to research children and youngsters as it allows first to make acquaintance and also it might be difficult for children to express themselves in writing. After conducting the interviews the recordings were transcribed. The data was analysed following the principles of a qualitative inductive content content analysis.

\section{The Sample}

The sample of the research is made up of 7 children who have a sibling in a special needs group in the kindergarten or at school, all aged 920 years, 4 boys and 3 girls. The age and type of the special need is illustrated in the chart (Chart 1). The research was conducted under a written permission from the parents and to ensure anonymity all participants were marked with a personal code that consists of a letter (L) and a number (1-7). 
Table 1. Age of children and type of special needs (Source: authors)

\begin{tabular}{|c|c|c|l|}
\hline Symbol & $\begin{array}{c}\text { Age of the } \\
\text { interviewee }\end{array}$ & $\begin{array}{c}\text { Age of sister or brother } \\
\text { with special needs }\end{array}$ & \multicolumn{1}{|c|}{ Type of special need } \\
\hline L1 & 11 & 8 & intellectual disability \\
\hline L2 & 16 & 11 & intellectual disability autism spectrum disorder \\
\hline L3 & 14 & 7 & multiple disability \\
\hline L4 & 20 & 24 & multiple disability \\
\hline L5 & 10 & 8 & intellectual disability autism spectrum disorder \\
\hline L6 & 13 & 5 & compound disability \\
\hline L7 & 9 & 13 & autism spectrum disorder and ADHD \\
\hline
\end{tabular}

\section{The Procedure of research}

The interviews to collect data were conducted in Tallinn between September 2018 and April 2019. The interviewees were introduced the objectives and structure of the interview before the start. It was emphasised that no name or data will be used in the research that might endanger their anonymity. The children had the choice to stop the interview or not to answer the question at any point. The children were asked if the interview can be recorded and all of them agreed.

\section{Results of Research}

\section{The experiences of the siblings of the cild with SEN}

The children in the sample were all aware of the special needs of their sibling. The children usually described their sibling with mainly positive words: funny, cool, sweet, special, caring, active, nice, kind, smart. At the same time, it was mentioned that the sibling can occasionally be: annoying, loud, disturbing and spiteful. It was pointed out that the actual age of their sibling is not in accordance with their appearance and behavior.
From the interviews it was found out that the children enjoy spending time with their families both at home and outside. They travel with the family, spend time taking walks, eating out, playing together. The sibling with SEN does not usually disturb the common activities of the family. At the same time however it was brought out that there are rather few common activities and it is difficult to get everyone involved. Due to the specificity of the behavior of the child with SEN the number of places they can visit is also limited. Children had noticed that doings of their parents were limited due to the child with SEN. It allows more different common activities and possibilities when there was an option to take the child with SEN to stay with the grandparents. One respondent for example mentioned: L5 My sister goes to stay with the grandparents for a week and then we have a lot of time to spend together /.../

Children prefer to spend their leisure time actively with mates, in practice, hobby group or at home dealing with their own things. They read books, play, study, spend time in their computer or 
smartphone. From active past-time activities horseriding, scootering and football were mentioned. Children have many hobby groups that help to pass time and to get away from the sibling with SN for a bit.

Most of the respondents said they enjoy spending time with their sibling and play games. For example, they play with toy cars, assemble puzzles, watch TV, play ball or go to the playground or for walks. The children in the sample care a lot about their sibling, one of the interviewees wants to go to sleep with her brother and to hold hands. The child with SEN can also be an idol for the sibling: L4 /.../my sister was like my idol /... / you cannot even tell that something is different when you're little. You don't pay attention to it as a child. The will to play grows if the children have common interests. Through games a child can teach the sibling with SEN new skills. It is considered great that one can play a role model for the sibling and teach them: $L 1 / \ldots /$ it is pretty cool that I have the kind of a brother who does not know too many things and then I can teach him everything. Often the skills and game preferences of the children with SEN are limited and it might be difficult for them to find things to do together. The sibling in that case needs often to act as per the will of the child with SEN. They do wish that they could engage with the sibling as per their own interests: $L 2$ /.../ I think it would be nice if I could have played with bim like football or something or gone to the movies with bim. To watch some other cartoons with him because he only watches the kind that he likes. He does not watch any others.

It was also pointed out that time is spent together however it is difficult to find mutual activities to do with the sibling with SEN. Multiple interviewees mentioned that playing ball is the only activity they can do together: $L 5$ We have played ball with her but it's like when she wants to play she can play for a while but when she doesn't then she gets bored and does not play anymore. Ant that is the only game I know that I can play with her. We roll the ball to each other.
The amount of duties for the siblings vary in families. Most of the interviewees said that they need to look after their brother or sister and do that even when the sibling is in their teen years already. This brings along the need to change plans. If the child with the SEN is not capable of servicing himself it might even mean changing diapers. One of the interviewees said: L2 / ... It has happened more than once /.../ that I'm at my friend's bouse and want to spend the night there but the parents want to go to the movies and so I need to go home to look after my brother even though he is no longer small. Multiple children described how they need to help to put their sibling to bed before they can go to sleep themselves. One of the children pointed out that she does not only put the sibling to bed but also needs to bring him home from the kindergarten. At the same time the child did not express any unwillingness towards the tasks by saying she does not mind at all.

The siblings described many occasions that made them feel that it is hard to be a family member to a child with special needs. For example, strangers staring at a relatively grown up sister in a stroller and therefore made her feel uncomfortable. The constant attention made her feel like she did not want to be with her sister due to the attention.

Many children with special needs have a hard time to understand behaviour patterns and they tend to do what they want. In a situation like these siblings try to support their parents and follow the wishes of the brother or sister. Multiple children acknowledged that it is difficult to understand what the brother or sister actually wants when they are unable to express themselves verbally. Often, they show their feelings by crying. It is also difficult to take care of a child with special needs as they do not understand the instructions given to them: $L 3$ /.../ he starts to cry if he wants sometbing but I do not understand what he wants... if only he could talk then I would understand. It was also mentioned that siblings with special needs can act unexpectedly and 
inappropriately in certain situations when reserved behaviour is expected. For example: L4 /.../ One time I have really felt embarrassed. My grandfather died and everyone were holding back the tears and my sister was just screaming at the funeral... But I understand, she cannot control her feelings.

It affects the siblings 'security when a parent spends a lot of time in the hospital with the brother or sister with special needs. The constant absence of the parents caused one girl to feel ambivalent emotions towards the sister with special needs: L4 /... / When my sister had that heart attack then she spent half a year in the hospital. Afterwards it was kind of a love-hate relationship with her. It literally meant that mom was missing, dad spent long days at the office, I was just left behind at my grandparents or somewhere else. I was thrown here and there like a bag. This is why I really cannot remember my childhood.

Depending on the specific special need the family members need to take into account different matters. For a child in a wheelchair they need to constantly check that the place is accessible. One of the interviewees expressed her distress that people often do not think about accessibility and there are still many establishments where it is difficult to visit with a wheelchair. Multiple children also mentioned behavioural specialities of the sibling with SEN that mean constant looking after them or make it hard to be with them. A child with the Asperger syndrome might be controlling and expect the whole family to act as per his logic. The coping of the family is also made more complicated by the fact that the child with special needs grows, gets stronger and faster which in turn means he might need different kind of support: $L 2$ /.../ one person can keep on eye on him but still you turn away for a moment and he is already doing something. So sometimes it takes more people to look after him. /.../ grandmother and grandfather cannot handle my brother just because they can't keep up with him anymore.

Many worries were shared by the siblings of children with SEN. One of them pointed out that his brother does not really have any friends outside of the family circle. For the brother to be able to talk and communicate better to make friends is the biggest dream for this child. It turned out that future is also a worry-point for the siblings. It was also brought out on multiple occasions that they would really like to know if their sibling is able to look after himself in the future and if the activities for development serve any good whatsoever. Families try and test frequently different therapies and ways how to develop the child with special needs. Therapies however are expensive, and they do affect financially: L2: ,, /... / I would like someone to confirm that he can get well. Because right now it is really expensive with all the therapies and dolphin therapies and stuff and I don't know if they really help. "

The interviewees named many reasons how their siblings have affected themselves. It was pointed out that when growing up with a brother or sister with special needs it makes one sensitive for any negative comments regarding the sibling. Personal experience makes these children more aware of the difficulties that may arise in a family raising a child with special needs. Monitoring your own health and rising the awareness of the friends was also mentioned. One child finds it important to take good care of yourself already when young to ensure healthy babies in the future. The child is also aware of what exactly comes with raising a child who needs more taking care of and this makes them avoid dangerous situations: whatever you can do to ensure nothing bad happens - do it. This is what I tell other people as well. /... / I will not go jump down from bigh spots or jump in the water in an unknown place because I know that life might become more difficult. I try to share the awareness among my friends as well.

Growing up in a family with a child with special needs makes his siblings to make an effort to make the parents's life easier. One interviewee is motivated to be better and try harder when seeing the parents struggling with the brother or sister with special needs. They try to make their parents 
happy by not partying, not smoking or drinking alcohol - instead they study hard: /.../ I feel like I don't know exactly how but my brother has made me a betterperson. /... / I try to be the best child one can be and I study bard.

\section{Supporting the siblings of a child with special needs}

To cope with the problems, issues and difficult emotions children often need support. The siblings of a child with special needs get most of the support from their friends and parents. There were children among the sample who tell their friends about the brother or sister with special needs: L1 "My support in that sense is the fact that I tell my friends about it. My friends bave visited us, and they already know what he is like and understand that he has a syndrome. "It was considered important that friends are understanding in regards to the brother or sister. It was also brought out that usually it is the mother who is more open and therefore easier to talk to about any worries. There were also children who prefer to share their concerns only among the family circle as the topic is delicate and private. They admitted that often no-one outside of the family knows about the existence of the family member with special needs as it is not a subject to be shared.

\section{Camps and support groups as a way to support}

All of the interviewees answered that they would happily take part of any support groups or camps that is organised for the siblings of a child with special needs. Some already had such experience. They thought it would be nice to be in camp with their brother or sister and meet other children with special needs: ... I would like to see other children so I would know what they are like and if they are anything like my brother. They hope that in addition to the experience their sibling with special needs might find new friends to play with. A camp that is for the whole family could be a way to get out of the everyday routine: L4 /.../ These camps during the summer is a way to get out of the everyday struggle which is really long... But there is too fen of these camps as there are not enough places accessible with a wheelchair.

A support group could be the place to meet and communicate. The children find it motivating to take part of such group or camp if they have a chance to get more information about how to help their brother or sister, to communicate and talk about experiences with other children and to really help their sibling: $L 7 /$ /... I could tell my things to the others, the ones who have similar siblings as I do and they understand and then we could share.

It was interesting to hear the thoughts of one interviewee who brought out as the reason of participating the wish to help other children in similar situation. She thought that talking about her own feelings could be a burden for other children and she did not really want that: $L 4 / \ldots /$ I think I would have taken part of the support group more for others than for myself. I like to help more. /... / Because I don't want anyone to worry about these things. They were not born to the family I was born in and I can manage.

\section{Discussion and Conclusion}

The aim of this research was to describe the experiences of siblings of a child with special needs, try to understand their support needs and to find out the need for support groups and camps.

The first question of the research was to find out what kind of experiences the siblings of a child with SEN have. It appeared that all siblings were well aware of the special needs and peculiarities. Theoretical sources also confirm that it is important to share the information about changes in the family life with the child as every change might come with anxiety and decrease of mood (Lindgren \& Suter, 1994, 92) 
All the children in the sample of this research enjoy spending time with their family however think that there should be more activities they could do together. Most poplar past time activities with the family are travelling, taking walks, going out to eat, playing board games and other games. The child with special needs does not usually disturb the family activities.

The behaviour of the child with SEN might set certain limitation and they can not be taken with to some places - this sets limits for the whole family. If the child with special needs is in a wheelchair then the family needs to constantly check that the place, they are planning to visit is accessible. Steel, Vandevelde, Poppe \& Moyson (2010, 235-237) also admit that the actual impact that the child with SEN has on the family is seen during holidays and leisure time. Whatever the activity is the place needs to be accessible and adapted to the child with SEN. The parents really need to plan ahead to avoid any possible errors.

The children in the sample prefer to spend their leisure time with friends or at home doing their own things. They go to practice or to their hobby group that help to get away from the home environment where the sibling with special needs is present.

Earlier researches also confirm that it is important for the siblings to have their space and the possibility to spend some time separately from the family member with special needs (Steel, Vandevelde, Poppe \& Moyson, 2010, 235-237). At the same time the siblings enjoy spending some time with the brother or sister with special needs and play different games with them.

Through common activities they teach their siblings new skills. The lack of skills and preferred activities set a certain limit and when choosing the activities the choice is narrowed as it is found that usually the wish of the child with special needs is favourable. The age gap between the siblings allows the model learning in a family meaning that the children are learning from each other (Keltikangas-Järvinen 2013, 47-50)

It appeared that the siblings have various tasks when it comes to the brother of sister with special needs, like taking them home from the kindergarten, looking after them and putting them to bed. Looking after them often comes with a large burden and tension as the sibling needs constant watch - the behaviour can be unpredictable. In a case of multiple disability, the taking care also means hygiene processes like changing diapers. Hogan (2012, 76-77m 95) notes that the siblings who help their brother or sister with special needs develop certain caretaker skills that might be useful for them in the future. Also, such children are more understanding and helpful compared to the ones who do not have such experience. The siblings might have also been turned to parenting and they might have regular tasks that a child their age should not have. These siblings have a higher risk to feel miserable as they do not have enough time for activities fit for their age or time to just spend with their friends. The children whose life is somewhat limited as they need to constantly take care of their brother or sister are called "young caretakers" by Aldridge \& Becker (1993). Their psychological coping may be damaged as caretaking often comes with difficult feelings and various issues like lack of time, relationship problems - feeling isolated, poor progress at school, conflicts between the needs of oneself and the one taken care of. (reference by Underdown, 2006, 100-101). The children in the sample did not bring out the aforementioned problems however certain parallels can be drawn when describing complex situations and difficulties.

It appeared that there are parents who do not burden their other children with duties related to the sibling with special needs as they themselves have made the decision to keep that child in the family and they try to manage. The parents have 
their thoughts on the future as it is most likely that one of the other siblings will become the main caretaker of the child with special needs. One of the main places of concern is the future of the sibling with special needs - to what extent will the other children in the family be able to manage and if the development activities in the childhood benefit anyone.

The siblings are aware of the difficulties that come with raising a child with special needs. They are empathic and sensitive to negative comments regarding people with special needs. They look after their health and try to raise awareness among their mates. Hogan (2012, 76-77) also claims that these children who grow up with a sibling with special needs understand the challenges that people with special needs need to cope with.

The second question in the research was to find out about the thoughts on support needs for the siblings of the brother or sister with SEN. The siblings turn mostly to their parents or friends to talk about their concerns. There are children who do not discuss anything related to the sibling with special needs outside of the family as they find it to be an extremely private matter. In some cases, they turned to someone impartial like a psychologist. From the parents it is usually the mother who is more open and to who they can turn to for support. When it comes to friends it is important that they are understanding towards the child with special needs. It was mentioned in the interviews that it would really help if there was an option to discuss matters with other children in a similar situation. Conway \& Meyer (2008) claim the parents to be the primary source of information for their children. Meyer \& Vadasy (2007, reference by Conway \& Meyer, 2008) admit that the wellbeing of the child with special needs will improve if their siblings receive relevant information and necessary support when they grow up. The culture dictates the way people seek for help, the attitude towards professional help and intervening as well as which strategies for coping are accepted (Kovshoff, Cebula, Tsai \& Hestings, 2017, 41-42).

The third question in the research was to find out the will and readiness to take part of any support groups or camps meant for the siblings of a child with special needs. It turned out that the children in the sample were interested in such gatherings. There were some who would only take part of the camp but not the support group. Some of the interviewees had already participated in such camps and had had positive experiences. The reasons for wanting to participate were as follows: sharing experience, gathering information, wish to help the brother or sister, wish to help other children, the opportunity to talk and communicate. The interviewees found that if a camp is meant for the whole family it would help to rest and get away from their everyday problems. Roberts (2015) has noted that participating in a support group helps to decrease the feeling of isolation and allows to share experiences. SibworkS support program that was conducted in Australia showed that the children who participated in the program had less emotional and behavioural disorders than the children in the control group. In addition, the participants' selfesteem, relationship with their sibling and the skill to cope with problems all improved.

This was a qualitative research where the sample was made up of 7 children and youngsters who had a sibling with special needs growing up in their family. When interpreting the results, one has to take into consideration the limitations of the research and no large generalisations can be made. To get a better overview of the subject the size of the sample needs to be increased and the situation with the siblings of a child with special need has to be studied all over Estonia as well as in other countries. It would be beneficial to compare the experiences of siblings of a child with special needs to the children who do not have siblings with special needs. This would help to understand if the 
experiences actually differ. We should also compare the vision of needed support between the parents and the siblings of a child with special needs. A support program and a long-term research should be conducted by comparing the situation before and after the program in order to get a better overview if support groups and camps would be beneficial.

\section{References}

Barker, P. \& Chang, J. (2013). Basic family therapy. John Wiley \& Sons, Incorporated.

Baumeister, Faber., \& Wallace, (1999). Coping and Ego Depletion. Recovery after the coping Process. In Snyder, C. R. (1999). Coping: the psychology of what works.

Bedford, V. H. \& Volling, B. L. (2003). A Dynamic Ecological Systems Perspective on Emotion Regulation Development within the sibling Relationship Context. In. Lang, F. R. \& Fingerman, K. L. Growing Together: Personal Relationships across the Life Span. Cambridge University Press.

Bronfenbrenner, U. (2009). The ecology of buman development: experiments by nature and design. Harvard University Press.

Burke, P. (2008). Disability and Impairment: Working with Children and Families. London: Jessica Kingsley Publishers.

Conway, S. \& Meyer, D. (2008). Developing Support for Siblings of Young People with Disabilities. Support for Learning, 23(3), 113-117. doi. 10.1111/j.1467-9604.2008.00381.x

Heckhausen, J. (2008). Soci(et)al Scaffolding of Individual Growth across the Life Span. In ilbereisen, R. K., \& Lerner, R. M. (2008). Approaches to positive youth development. SAGE Publications.
Hogan, D. P. (2012). Family Consequences of Children's Disabilities. United States: Russell Sage Foundation.

Keltikangas-Järvinen, L. (2013). Vä̈kelapse sotsiaalsus. Tallinn: Koolibri.

Kiis, K. (1999). Pundelaste perede sotsiaalne toimetulek Tartu linnas. Tartu: Tartu Ülikool.

Klefbeck, J. \& Ogden, T. (2001). Laps ja võrgustikutōo. Tartu: Omanäolise kooli arenduskeskus.

Kovshoff, H., \& Cebula, K., \& Tsai, H-W. J., \& Hastings, R. P. (2017). Siblings of Children with Autism: the Siblings Embedded Systems Framework. Autism Spectrum (4), 37-45.

Laherand, M-L. (2008). Kvalitatiivne uurimisviis. Tallinn: OÜ Infotrükk.

Lindgren, H. C. \& Suter, W. N. (1994). Pedagoogiline psühholoogia koolipraktikas. Tartu: Tartu Ülikooli kirjastus.

Mangs, K., \& Martell, B. (2000). Psübhoanalüütiline arengukäsitlus 0-20 eluaastani. Tartu: Tartu Ülikooli Kirjastus.

Meyer, D. \& Vadasy P. F. (2007). Sibshops: Workshops for Siblings of Children with Special Needs. United States: Brookes Publishing.

Minuchin, S. (1974). Families and family therapy. Harvard University Press.

Saldana, J. (2011). Fundamentals of qualitative research. Oxford University Press

Underdown, A. (2006). Young children's health and well-being. McGraw-Hill Education.

Veisson, M. (2000). Disabled children - The psychological status of parents and the social network of siblings. Göteborg: University of Göteborg.

Wodarski, J. S., \& Dziegielewski, S. F. (Eds.). (2002). Human behavior and the social environment: Integrating theory and evidence-based practice. Springer Publishing Company. 